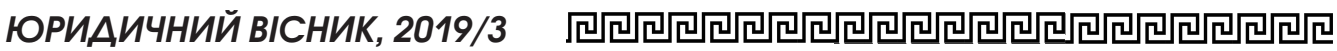

УДК 342.98

DOI https: / / doi.org/10.32837 / yuv.v0i3.950

Н. Сергієнко,

кандидат юридичних наук, старший викладач кафедри публічного та приватного права

Київського університету імені Бориса Грінченка

\title{
ДО ПИТАННЯ ПРАВОВОГО СТАТУСУ ДЕРЖАВНОГО ВИКОНАВЦЯ
}

Вже не один рік в Україні триває процес реформування виконавчого провадження. При цьому, змін зазнала як організація примусового виконання рішень, так і процес примусового виконання рішень. Однак, на превеликий жаль, наша держава поки що не може похвалитися тим, що рішення судів, інших органів (посадових осіб) виконуються повно, своєчасно та неупереджено. Безпосереднє примусове виконання рішень на підставі виконавчого документа, поданого до відповідного органу державної виконавчої служби (надалі - ДВС), здійснює державний виконавець. Враховуючи вказане, доцільним $є$ розгляд питання правового статусу державного виконавця. Питання правового статусу державного виконавця так чи інакше були розглянуті в наукових працях С. Я. Фурси, А. М. Авторгова, Р. В. Ігоніна, С. В. Щербак та інших науковців-юристів. А між тим, правове регулювання як організації примусового виконання рішень, так і процесу примусового виконання рішень змінюється достатньо динамічно, практика примусового виконання рішень йде вперед та ставить перед юристами-науковцями та юристами-практиками все нові і нові виклики. Враховуючи вказане, актуальним видається нове осмислення питання правового статусу державного виконавця. Метою цієї наукової статті $€$ дослідження правового статусу державного виконавця в Україні в умовах сьогодення. Завданням наукової розробки в межах статті $є$ аналіз правового регулювання статусу державного виконавця через багатоаспектність такого правого статусу.
Під правовим статусом можна розуміти сукупність прав та обов'язків фізичних та юридичних осіб [1, с. 237], багатоаспектну, комплексну, універсальну категорію, що має чітку стабільну структуру, та встановлює характер та принципи взаємодії суспільних відносин між собою, а також шляхом визначення прав, обов'язків та гарантій їх реалізації, визначає місце суб'єкта в системі правовідносин [2, с. 95]. Як видається, «серцевиною» правового статусу відповідного суб'єкта можна визначати саме його права та обов'язки, адже гарантії їх реалізації напряму з ними пов'язані та уадекватнені ним, характер та принципи взаємодії різних суб'єктів правовідносин також напряму залежать від прав та обов'язків суб'єктів, обумовлюються ними.

Положення ст. ст. 7-8 Закону України «Про органи та осіб, які здійснюють примусове виконання судових рішень i рішень інших органів» передбачають, що державними виконавцями $є$ керівники органів державної виконавчої служби, їні заступники, головні державні виконавці, старші державні виконавці, державні виконавці органів державної виконавчої служби. Державні виконавці визначені державними службовцями.

Варто погодитись 3 А. М. Авторговим, який досліджуючи питання адміністративно-правового статусу державного виконавця, зазначає, що правовий статус - складова загальної проблеми прав особистості [3, с. 10]. Дійсно, держаний виконавець - в першу чергу людина, громадянин України, який реалізував своє право на працю, шляхом здійснення тру- 
дової функції в одному з органів ДВС, яка (трудова функція) в основному сутнісно зводиться до безпосереднього примусового виконання рішень. Покладаючи на державного виконавця ряд обов'язків та надаючи йому відповідні права щодо примусового виконання рішень, держава, від імені якої і діє державний виконавець, будучи уповноваженим нею, декларує надання специфічного захисту державному виконавцю - гарантій діяльності державного виконавця, які покликані забезпечити, з одного боку, збалансування його прав та інтересів як громадянина та обмежень, пов'язаних з тим, що він є державним службовцем; а 3 іншого - забезпечити можливість здійснення ним примусового виконання рішень повно, всебічно, у строки, визначені законом.

В першому випадку, зокрема, мова може йти про дієвий механізм мотивування державних виконавців (п. п. 2 ч. 1 ст. 9 Закону України «Про органи та осіб, які здійснюють примусове виконання судових рішень і рішень інших органів»), в контексті якого можна виокремити право державного виконавця на отримання винагороди, у випадку забезпечення ним повного / часткового виконання рішення майнового характеру, повного виконання рішення немайнового характеру (ст. 13 Закону України «Про органи та осіб, які здійснюють примусове виконання судових рішень і рішень інших органів», Порядок виплати винагород державним виконавцям та ї розміри і розмір основної винагороди приватного виконавця, затверджений постановою Кабінету Міністрів України від 08 вересня 2016 р. № 643 [4]); специфічну структуру заробітної плати посадовий оклад, премії, доплати за ранг та надбавки за вислугу років, винагороди, а також інших надбавки згідно із законодавством (ч. 1 ст. 13 Закону України «Про органи та осіб, які здійснюють примусове виконання судових рішень i рішень інших органів»). Тут можна говорити про певне балансування реалізації громадянином своїх конституційних прав та гарантій та специфіки статусу такого громадянина як державного виконавця, а отже - особи, яка діє не від свого особистого імені, а від імені держави та реалізує іï функціі. Зокрема, громадянин реалізував свої конституційні права на працю (ст. 43 Конституції України), на доступ до державної служби (ч. 2 ст. 38 Конституції України), вільно погодившись стати держаним виконавцем, однак одночасно і отримавши обов'язок дотримуватись обмежень, визначених законодавством про державну службу (наприклад, положеннями ст. 44 Конституції України передбачено право тих, хто працює на страйк, а заборона страйку можлива лише на підставі закону. Законом України «Про державну службу» (ч. 5 ст. 10) встановлено, що державний службовець не має права організовувати і брати участь у страйках; положеннями ст. 36 Конституції України передбачено, що громадяни України мають право на свободу об'єднання у політичні партіі. Обмеження щодо членства у політичних партіях встановлюються виключно цією Конституцією і законами України. Державний службовець не має права бути членом політичної партії, якщо такий державний службовець займає посаду державної служби категорії «А», обіймати посади в керівних органах політичної партії (п. п. 1, 2 ч. 3 ст. 10 Закону України «Про державну службу».). Приписами статті 47 Конституції України передбачено право кожного на житло. В цьому контексті варто зауважити, що державні виконавці, які потребують поліпшення житлових умов, забезпечуються службовим житлом у першочерговому порядку на час виконання повноважень відповідно до законодавства за кошти державного чи відповідного місцевого бюджету. За сім'єю загиблого державного виконавця зберігається право на одержання жилої площі (ч. 14 Закону України «Про органи та осіб, які здійснюють примусове виконання судових рішень і рішень інших органів»).

В другом випадку, держава надає гарантії можливості ефективного виконання свого основного завдання дер- 


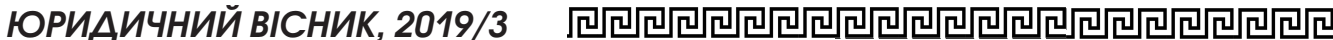

жавним виконавцем - примусового виконання рішень. Тут можна згадати про особливий порядок фінансування та матеріально-технічного забезпечення органів державної виконавчої служби (фінансове та матеріальне забезпечення діяльності працівників органів державної виконавчої служби та фінансування витрат на проведення і організацію виконавчих дій здійснюються за рахунок коштів державного бюджету, а також коштів виконавчого провадження ч. 1 ст. 14 Закону України «Про органи та осіб, які здійснюють примусове виконання судових рішень і рішень інших органів»); прозорість діяльності 3 примусового виконання рішень (наприклад, фіксування виконавчих дій здійснюється в автоматизованій системі виконавчого провадження, до якої кожен охочий може мати вільний та безоплатний доступ через мережу Інтернет ч. 1 ст. 8 Закону України «Про виконавче провадження», а сторони виконавчого провадження за допомогою відповідного ідентифікатора можуть через мережу Інтернет ознайомлюватись з матеріалами виконавчого провадження, мати доступ до узагальненої інформації про рішення (виконавчі діiі), прийняті (вчинені) виконавцем, із зазначенням дати їх прийняття (вчинення) та 3 можливістю роздрукування такої інформації (п. 2 розділу VI Положення про автоматизовану систему виконавчого провадження, затверджену Наказом Міністерства юстиції України 05.08.2016 № $2432 / 5$ [5]).

Державний виконавець є суб'єктом виконавчого процесу, відтак, реалізує в ньому свої відповідні процесуальні права та обов'язки. Щодо останніх (права та обов'язки державного виконавця як суб'єкта виконавчого процесу), то вони передбачені як актами виконавчого процесуального законодавства (зокрема, ст. 18 Закону України «Про виконавче провадження», окремі з них деталізовані в Інструкції 3 організації примусового виконання рішень, затвердженій Наказом Міністерства юстиції України від 02.04.2012 № 512/5 [6]), так й інших галузей законодавства, наприклад, про- цесуального: ЦПК України, ГПК України, КАС України (зокрема в аспектах регулювання вирішення судами питань, пов'язаних 3 примусовим виконанням рішень). Основний комплекс прав та обов'язків державного виконавця при виконанні різних категорій справ у певному обсязі той самий. Однак, ряд процесуальних дій, а у зв'язку з цим і прав та обов'язків, мають своєрідний характер та різне значення залежно від категоріі виконавчого документа [7, с. 194].

На перший погляд може здатися, що передбачені ч. 3 ст. 18 Закону України «Про виконавче провадження» права виконавця (зокрема, і державного виконавця), це не стільки його права, стільки обов'язки. А. М. Авторгов наголошує на тому, що для держаного виконавця первинними є обов'язки, які і окреслюють загалом межі його правового статусу. У процесі здійснення своїх прав державний виконавець діє в юридичних межах, визначених його обов'язками [3, с. 11]. Як видається, проблема, що ж є первинним для державного виконавця - його права чи обов'язки, розв'язується через звернення до іншої категорії - завдання, яке стоїть перед державним виконавцем. Положення ст. 3 Закону України «Про органи та осіб, що здійснюють примусове виконання судових рішень і рішень інших органів» таким завданням визначають своєчасне, повне і неупереджене виконання рішень. Твердження про примат обов'язків державного виконавця перед його правами видається передчасним, адже будучи зобов'язаним вжити заходів примусового виконання рішення шляхом вчинення відповідних виконавчих дій, виконавець має вчинити такі виконавчі дії, в тому числі, ефективно (ч. 1 ст. 18 Закону України «Про виконавче провадження»). Для реалізації вказаного вище завдання та на виконання вищеокресленого обов'язку у виконавця наявний цілий спектр прав, зокрема, визначений ч. 3 ст. 18 Закону України «Про виконавче провадження». Відтак, повинен мати місце розумний розсуд виконавця щодо вчинення ним відповідних виконавчих дій (серед широ- 
кого спектру прав виконавця, він має самостійно визначати, яке і коли 3 них реалізувати, щоб забезпечити своєчасне, повне та неупереджене виконання рішення, що примусово виконується адже саме це завдання виконавця, відповідно до ст. 3 Закону України «Про органи та осіб, що здійснюють примусове виконання судових рішень і рішень інших органів»). Наявність розсуду визначається тими обставинами, що в нормі права міститься лише загальна модель поведінки, а конкретна життєва ситуація завжди змістовно багатша [3, с. 11]. Враховуючи наявність у державного виконавця адміністративно-правового статусу, в наведеному вище аспекті, можна звернутися до поняття адміністративного розсуду як правозастосовчої діяльності адміністративного органу щодо використання можливого варіанту поведінки, передбаченого законом, на власний розсуд під час вирішення поставлених перед ним завдань, спираючись при цьому на принципи, що регулюють їх діяльність [8, с. 14]. Гарантовану законом можливість відповідного суб'єкта вільно та незалежно розпоряджатися своїми матеріальними та процесуальними правами, а також засобами захисту В. В. Золотаренко розглядає зокрема і в аспекті диспозитивності як одного $з$ принципів виконавчого провадження [9, с. 38]. Між іншим, наведений автор вказує, що у свою чергу, виконавець повинен діяти неупереджено (ч. 1 ст. 18 Закону - мається на увазі Закон України «Про виконавче провадження» - курсив мій), а заінтересованість в результаті виконання рішення $€$ підставою для відводу виконавця, експерта, спеціаліста, суб'єкта оціночної діяльності - суб'єкта господарювання, перекладача (ч. 4 ст. 5, ст. 23 Закону мається на увазі Закон України «Про виконавче провадження»- курсив мій). Вихідним принципом діяльності виконавця є принцип законності - обов'язок діяти лише на підставі, в межах повноважень та у спосіб, що передбачені Конституцією та законами України. У випадку наділення державного органу дискрецій- ними повноваженнями межі їх реалізації повинні бути чітко визначені у законодавстві [9, с. 39]. Беззаперечно, державний виконавець має діяти лише на підставі, в межах повноважень та у спосіб, що передбачені Конституцією та законами України, в цьому виявляється, в тому числі, і принцип законності, який $€$, поруч $з$ принципом диспозитивності, одиним з принципів виконавчого провадження. Однак, як видається, законність та диспозитивність як принципи виконавчого провадження не $є$ взаємосуперечними, а навпаки - взаємодоповнюючі принципи виконавчого провадження. Обидва вони виявляються і в діях державного виконавця (наприклад, з одного боку, державний виконавець має вчиняти діяння та приймати рішення виключно в межах закону, з іншого боку, самим же законом передбачено наявність у виконавця цілого спектру процесуальних прав, які він може реалізовувати на власний розсуд, одночасно будучи «зв'язаним» завданням, яке стоїть перед ним як особою, яка безпосередньо примусово виконує рішення - своєчасне, повне i неупереджене виконання рішень). Як видається, твердження, що «...заінтересованість в результаті виконання рішення $є$ підставою для відводу виконавця...» [9, с. 39] є дещо категоричним. Адже слід розрізняти особисту заінтересованість у результатах виконавчого провадження та державну, оскільки остання має зумовлюватися правовими зв'язками всіх державних органів щодо виконання державних функцій [7, с. 228], а підстави для відводу державного виконавця чітко визначені приписами ч. 4 ст. 5 Закону України «Про виконавче провадження».

Узагальнюючи вищевказане, можна резюмувати наступне. В контексті прав та обов'язків державного виконавця, 3 врахуванням вказаного вище, слід артикулювати, що вони являють собою холістичну (цілісну) структуру, що обумовлена конституційно-правовим (адже державний виконавець, в першу чергу, це людина, громадянин, який має весь спектр прав та обов'язків, передбачених Конституцією України, однак особли- 


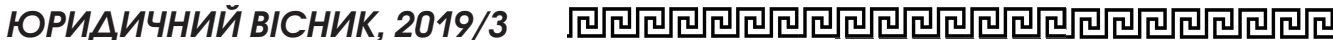

вості реалізації деяких з них пов'язані 3 його статусом як державного службовця, суб'єкта виконавчого процесу), адміністративно-правовим (державний виконавець - це державний службовець, відповідно, має права та несе обов'язки, передбачені законодавством про державну службу), виконавчим процесуальним (державний виконавець - суб'єкт виконавчого процесу, отже, наділений відповідними правами та обов'язками, необхідними для здійснення примусового виконання рішень) аспектами. Перспективними видаються й подальші наукові розробки тематики правового статусу державного виконавця, адже полігранність наукової думки розвиває науку та дає більш повні відповіді на запити практики.

У науковій статті розглянута проблематика правового статусу державного виконавия. Здійснено аналіз приписів чинних нормативно-правових актів, які визначають права та обов'язки державних виконавців. Будучи суб'єктом виконавчого процесу, державний виконавець реалізуе в цій юрисдикиійній діяльності свої процесуальні права та обов'язки. Однак, водночас, державнии виконавецьь $е$ суб'єктом владних повноважень, тому має діяти у відповідності з законом. у иьому ж контексті виявляється законність як один з принципів виконавчого провадження. Своєчасне, повне та неупереджене виконання рішення - завдання державного виконавия в ході виконавчого провадження. У зв'язку з наведеним постає необхідність у розумному розсуді державного виконавия у виконавчому провадженні - можливості обирати, яке право сліо реалізовувати для досягнення завдання виконавчого провадження своєчасного, повного та неупередженого виконання рішення. На думку автора, розумний розсуд ие спеціальна прерогатива державного виконавия з одного боку, а з іншого боку - ие частина відповідальності державного виконавия. Виконавче провадження здійснюеться на певних принщипах (див. ст. 2 Закону України «Про виконавче провадження»). Законність та диспозитивність серед них. На думку автора, законність та диспозитивність як деякі принципи виконавчого провадження не протидіють одне одному, а доповнюють один одного. Вони різні, але вони взаємопосилюючі, існують в специфічній єдності. Вони виявляються $i$ у діяльності державного виконавия. Державний виконавець водночас має діяти виключно на підставі закону (тому щзо він є суб'єктом владних повноважень), однак, при прийнятті рішень має керуватись $і$ розумним розсудом - не буває однакових життевих ситуацій, тому й однакової формули як діяти немає. У статті зроблено висновок, шцо права та обов'язки державного виконавия перебувають в єдності, щуо є необхідним для примусового виконання рішення. Подальші наукові розробки теми статусу державного виконавия видаються перспективними, оскільки різноманітність наукових думок вдосконалюе науку $i$ дає більщ повні відповіді на питання практики.

Ключові слова: правовий статус, державний виконавець, права, обов'язки.

\section{Sergiienko N. ON THE QUESTION ONLEGALSTATUSOFGOVERNMENT EXECUTOR}

The problematic of government executor legal status has been considered in the scientific article. The prescriptions of acting legal acts that determine government executors' rights and obligations have been analyzed and researched. Government executor being the subject of executive process, realizes in this jurisdictional activity its procedural rights and obligations. But in the same time, government executor is the subject of public authority, so must act in compliance with the legislation. In this manner, the legality as one of the principles of executive process realizes. Execution 
the decisions in time, fully and unbiased - is the aim of government executor during executive process. That is why there is the necessity of smart discretion of government executor during executive process - to choose what right to realize for provision matching the aim of executive process - execution the decisions in time, fully and unbiased. Smart discretion, as it is thought by the side of the author, is the special prerogative of government executor from the one side, and it is the part of government executor liability from other side. There exist different principles of executive process (see art. 2 The Law of Ukraine "On Executive Process"). Legality and dispositivism are among them. The author guess that legality and dispositivism as some principles of executive process are not in contradiction, they add each other. They are different, but they strengthen each other, they exist in a special consolidation. All they can be stated also in activities of government executor. In the same time the government executor must act only in in compliance with the legislation (because of the status of public official), but also makes decisions grounding on the smart discretion - there are different life situations and no one formula how to act. There is concluded in the scientific article that government executors' rights and obligations exist in unity, it is necessary for compulsory execution of decision. Other scientific researches of the theme of government executor legal status are imagined as perspective because of the thesis that multiplicity of scientific thought improve science and give more full answers to questions of practice.

Key words: legal status, government executor, rights, obligations.

\section{Література}

1. Мала енииклопедія теорії держави $i$ права / За заг.ред. Ю. Л. Бошицького. К. : видавниитво Європейського університету. 2010. 368 c.
2. Панчишин А. В. Поняття, ознаки та структура категорії «правовий статус». Часопис Київського університету права. 2010. № 2. C. 95-98.

3. Авторгов A. M. Адміністративно-правовий статус державного виконавия. Автореферат дисертації на здобуття наукового ступеня кандидата юридичих наук. 12.00.07 - адміністративне право i процес; фінансове право; інформаційне право. Київ. 2008. 19 с.

4. Порядок виплати винагород державним виконавиям та їх розміри і розмір основної винагороди приватного виконавия : постанова Кабінету Міністрів України від 08 вересня 2016 р. № 643. Верховна Рада України. Офіиійний веб.сайт. https:// zakon.rada.gov.ua/laws / show/643-2016-n. Дата звернення: 02.07.2019.

5. Положення про автоматизовану систему виконавчого провадження : Наказ Міністерства юстиції України 05.08.2016 №2432/5. Верховна Рада Украӥни. Офіційний веб. Сайт. https: / / zakon.rada.gov.ua / laws / show / z1126-16\#n16. Дата звернення 02.07.2019.

6. Інструкція з організації примусового виконання рішень: Наказ Міністерства юстицї України від 02.04.2012 № 512/5 (y редакціїнаказу Міністерства юстиції Украіни 29.09.2016 № 2832/5). Верховна Рада України. Законодавство України. https: / / zakon.rada.gov.ua/laws/show/z0489-12. Дата звернення 21.11.2019.

7. Фурса С. Я. Закони України «Про державну виконавчу службу», «Про виконавче провадження», «Про виконання рішень та застосування практики Європейського суду з прав людини»: науково-практичний коментар / С. Я. Фурса, Є. I. Фурса, С. В. Щербак ; за заг. ред. С. Я.Фурси ; Центр правових досліджень. - Київ : Фурса C. Я. : KHT, 2008. -1172 c.

8. Лагода О. С. Адміністративна процедура: теорія практика застосування. Лагода Олександр Сергійович. Автореферат дисертаціï на здобуття наукового ступеня кандидата юридичних наук. Спеціальність 12.00.07 - адміністративне право і процес; фінансове право; інформащійне право. Iрпінь. 2007. $22 \mathrm{c}$.

9. Золотаренко В. В. Реалізація принuипу диспозитивності у діях субєктів виконавчого провадження. Цивілістична процесуальна думка. 2016. № 4. С. 38-41. 